

\title{
LA ORDEN DE ALCÁNTARA DURANTE LA EDAD MEDIA SEGÚN LA DOCUMENTACIÓN PONTIFICIA: SUS \\ RELACIONES INSTITUCIONALES CON LAS DIÓCESIS, EL CÍSTER, OTRAS ÓRDENES MILITARES Y LA MONARQUÍA (SEGUNDA PARTE)
}

POR

\author{
Luis Corral Val
}

Universidad Complutense

\section{Resumen}

El autor da a conocer los primeros resultados de su investigación sobre los fondos medievales referidos a la orden de Alcántara que se conservan, principalmente, en los Archivos Vaticanos, la Real Academia de la Historia y la Biblioteca Nacional de Madrid. En esta segunda entrega expone sus conclusiones históricas, a la luz de la rica documentación pontificia, acerca de las relaciones de dicha orden con las dícesis circundantes, el Císter, otras órdenes militares y la monarquía.

\section{Abstract}

The author offers his first researches about the medieval holdings of the Order of Alcantara that are mainly located in the Vatican Archives, in the Spanish Academy of History and in the National Library in Madrid. In this second part he exposes his historical conclusions - according to the papal documentationabout the relationship of the Order of Alcantara with the episcopal jurisdiction, the Order of Citteaux, others Military Orders and the Monarchy.

La rica documentación pontificia que he recopilado durante estos últimos años sobre la orden del Pereiro-Alcántara proyecta abundante luz sobre algunos temas de su historia institucional que siempre han quedado en la penumbra 
debido, principalmente, a la pérdida de su archivo central a comienzos del siglo XIX, tal y como expuse en la primera parte de este trabajo'. Esta documentación me permite un primer acercamiento histórico - aún muy general y sólo desde la perspectiva pontificia - a una parte de la historia institucional de la orden: relaciones con las diócesis, su filiación al Císter, y las relaciones institucionales con otras órdenes militares y con la monarquía.

\section{LA ORDEN DEL PEREIRO-ALCÁNTARA Y LAS DIÓCESIS.}

La aparición de la hermandad militar de San Julián del Pereiro, cuyo propósito era la lucha contra los islamitas en los confines del reino leonés, fue acogida en un primer momento con agrado y confianza por los prelados diocesanos. Éstos compartían con los freires el mismo interés por expulsar a los musulmanes de la península ibérica. Sin embargo, con el paso del tiempo, la orden del Pereiro-Alcántara fue adquiriendo un relevante poder territorial, jurisdiccional, político y económico, que empezó a ser visto como una amenaza por las dignidades diocesanas. Los freires militares, al intentar ejercer su dominio sobre distintos territorios y querer preservar su poder jurisdiccional, económico, territorial y político, chocaron con los arzobispos y obispos de las diócesis donde había encomiendas alcantarinas. Pronto los freires fueron adquiriendo una sombría fama, entre los prelados de las distintas diócesis, de ambiciosos, violentos, incultos, usurpadores de los derechos diocesanos y de pretender actuar al margen de los obispos, parapetándose en su sujección inmediata o dependencia prioritaria respecto a la sede apostólica².

I L. CORRAl VAl, "La orden de Alćntara y el Papado durante la Edad Media según la documentación pontificia" (primera parte), Hispania Sacra 49 (1997), pp. 601-623. En esta segunda parte seguimos idénticos criterios a los expuestos en su día sobre abreviaturas y notas a pie de página: para no recargar en exceso el aparato erudito śblo citamos la copia más fiable de los documentos pontificios, excepto si no podemos determinar cuál es; en dicho caso citamos todas las copias manuscritas. Algunas de estas bulas están publicadas, regestadas o citadas en diversos trabajos históricos. Retrasamos hasta el momento en que se publique la Colección Diplomática Medieval de la orden de Alcántara las referencias a esos trabajos. Dicha Colección Diplomática, dirigida por el Dr. Palacios Martín, y en la que tenemos el honor de colaborar, pretende paliar la laguna documental e historiografica sobre dicha orden mediante el recurso a la documentación publicada antes de la pérdida del archivo central y al rastreo sistemático de aquellos archivos, bibliotecas o instituciones que puedan contener documentos relativos a la orden de Alcántara (vid. el alcance y significado de este ambicioso proyecto en: B. PALACIOS, "Proyecto Alcántara. Un intento de reconstrucción de la Colección Diplomática de la orden de Alcántara", Medievalismo 5 (1995), pp. 301-304).

${ }^{2}$ En 1995 apareció un interesante libro del que no pudimos dar noticia en la primera parte de este trabajo al referirnos a la exención de la orden con respecto a la jurisdicción episcopal y su dependencia directa respecto al papado: L. García-GulJarro, Papado, cruzadas y ordenes militares, siglos XI-XIII, Madrid 1995. Este autor critica los planteamientos institucionalistas que, al identificar

Medicvalia Hispanica

Hispania Sacra 50 (1998) 
Uno de los litigios principales, según observamos en la documentación pontificia, entre obispos y freires, fue el de los diezmos. Alejandro III había establecido en 1176 que de los novales, que por sus propias manos o a sus expensas los sanjulianistas cultivaban, o de las crías de los animales, nadie osara reclamar diezmos ${ }^{3}$. Lucio III ratificó el mismo privilegio seis años y medio después ${ }^{4}$. El canon 55 del IV Concilio de Letrán obligó a todos los religiosos regulares a pagar los diezmos de sus tierras a las parroquias donde residían, incluyendo en esta norma las tierras que les regalaban los fieles, que debían seguir pagando los diezmos, tanto si las trabajaban los religiosos, como si las vendían o encomendaban a otros para que las labraran. Sólo quedaban exentas las tierras que los regulares roturaban de nuevo, es decir, los novales. Este canon era el estadio final de una larga lucha de Inocencio III por imponer esta disposición a los premonstratenses y cistercienses, y después a todos los regulares. Anteriormente, la sede apostólica reconocía la exención de tierras que los regulares trabajaran con sus propias manos o a sus expensas ${ }^{5}$, sin embargo, los sanjulianistas sólo gozaron -al menos desde 1176- del privilegio referido a los novales.

Otro gran problema fue el de la fundación de iglesias y oratorios y el nombramiento de clérigos para regirlos. En este apartado, como también en el referido a sepulturas y consagración y bendición de iglesias y cementerios, fue donde mejor se apreciaba la existencia de una sumisión secundaria de las órdenes militares a los obispos, compatible con la dependencia prioritaria de las mismas respecto al papado, si seguimos el modelo explicativo de García-

exención con dispensa de poder de corrección del ordinario, condujeron a la investigación por la vía de la búsqueda del privilegio introductor y de clausulas que delatasen la supresión de la jurisdicción episcopal. Para el Dr. García-Guijarro es necesario que el investigador se coloque en el camino de una consideración menos restrictiva de la exención; ligada no tanto a un fenomeno concreto (la potestad jurisdiccional del obispo y la anulación de cualquier obediencia al diocesano) como al lento, y a veces contradictorio, surgimiento de la dependencia al papado jniciado con la protección. También el estudioso debe tener en cuenta que la presencia de rasgos de jurisdicción diocesana dejaba incólume la existencia de una superior jurisdicción papal, porque había compatibilidad de obediencias -aunque con peligro de interferencias - y porque el despliegue de la prioritaria no se producía sin contradicciones. Podía darse potestad episcopal, emanada de la tradicional dependencia monástica al ordinario, junto a un creciente dominio pontificio, nacido del nuevo lazo establecido por la protección y tutela papal.

3 "Sane novalium vestrorum, que propriis manibus, aut sumptibus colitis, sive de nutrimentis vestrorum animalium, nullus a vobis decimas presumat exigere" (bula del 29 de diciembre de 1176: B) B.N., ms. 622, ff. 6r-7v; C) R.A.H., Col. Sal., J-19, ff. 180r-182r; D) A.H.N., OO. MM., Reg. Escrituras Calatrava, t. I, f. 58).

4 Bula del 4 de abril de 1183: B) A.C.C., leg.. 276, $\pi^{\circ}$. 18; C) B.N., ms. 621, ff. 135r-138v; ff. 143r-146r; D) R.A.H., Col. Sal., I-19, ff. 184r-187r; I-37, f. 43r-v.

5 A. García Y García, "La vida monástico-religiosa en el Concilio IV Lateranense" en Iglesia, sociedad y derecho, 2, Salamanca 1987, pp. 165-166. 
Guijarro $^{6}$. Inocencio IV7 o Nicolás $\mathrm{V}^{8}$, por ejemplo, defendieron que los alcantarinos pudiesen fundar iglesias o capellanías dentro de los límites territoriales de las diócesis. Esto provocaba que los obispos perdieran gran parte de sus derechos y rentas, y que los freires y sus iglesias mantuvieran una exagerada independencia - según el punto de vista episcopal - con respecto a los obispos diocesanos. También los papas concedieron a los alcantarínos la prerrogativa de presentación de presbíteros y clérigos seculares como párrocos en las iglesias del maestrazgo de la orden'. Todos estos privilegios y otros complementarios iban en la misma línea: conceder mayor autoridad a los alcantarinos en sus iglesias y capellanías evitando cualquier presión - por ejemplo, mediante censuras eclesiásticas u otros medios- por parte de los obispos. Pero, hay que reconocer que éstos no se resignaron fácilmente a perder sus derechos jurisdiccionales y sus rentas en las iglesias de las ordenes militares. Por tanto, la pugna se perpetuó durante toda la Edad Media.

Otro frente conflictivo fue el relativo a sepulturas, la "donatio post obitum", derechos mortuorios y últimas voluntades de los fieles. Los papas establecieron la libertad de sepultura y el respeto por la última voluntad del finado, dejando a salvo el derecho de las iglesias de donde los cuerpos procediesen ${ }^{10}$. Estas disposiciones, sin embargo, se prestaban a interpretaciones partidistas, sobre todo por parte diocesana, que aprovechaba la ambigüedad papal para no perder los fructíferos enterramientos que les podían arrebatar los freires. El pontificado protegió a los freires con más eficacia en el asunto de los bienes dejados como última voluntad ${ }^{11}$. Muchos fieles y familiares de la orden hicieron donación de sus bienes a los sanjulianistas o alcantarinos para remedio y salvación de sus almas. Pero, los diocesanos procuraban limitar dichas cesiones o impedir que las donaciones tuviesen efecto, por lo que los freires se veían obligados a buscar amparo ante la sede apostólica.

\footnotetext{
6 L. García-GuIJarro, Op. cit., p. 137.

7 Bula del 26 de marzo de 1246, cita A. de TORRES Y TAPIA, Crónica de la Orden de Alcántara, Madrid 1763, I, p. 311.

8 Bula del 1 de octubre de 1451: B) A.S.V., Reg. Vat. 397, f. 332r-v.

' Bula del 24 de noviembre de 1426: B) R.A.H., Col. Sal., I-19, ff. 253r-254r.

10 "Sepulturam quoque ipsius loxi liberam esse decernimus, ut eorum devotioni, et extreme voluntati, qui se illic sepeliri deliberaverint, nisi forte excommunicati, vel interdicti sint, nullus obsistat, salva tamen iustitia illarum ecclesianum, a quibus mortuorum corpora assumuntur" (bula citada del 29 de điciembre de 1176). La misma disposición fue ratificada por Lucio III (bula citada del 4 de abril de 1183).

11 Bula del 18 de marzo de 1238: B) B.N., ms. 622, f. 205r-v; C) R.A.H., Col. Sal., I-19, f. 217rv. Bula del 19 de marzo de 1238, ed. I. J. de ORTEGA Y COTES; J. FERNÁNDEZ DE BRIZUELA; P. de ORTEGA ZÚÑIGA Y ARANDA, Bullarium Ordinis Militiae de Alcántara, olim S. Juliani del Pereiro, Madrid 1759, p. 48. Bula del 24 de marzo de 1238, ed. I. J. de ORTEGA Y COTES, Bullarium de Alcántara, pp. 48-49.

Medievalia Hispanica Hispania Sacra 50 (1998)
} 
Las penas y censuras eclesiásticas fueron utilizadas con frecuencia por los obispos en contra de los sanjulianistas o alcantarinos. Recordemos al lector contemporáneo que eran muy eficaces en aquellos tiempos medievales, tan sensibles ante las sanciones canónicas de los prelados eclesiásticos. Los freires buscaron la ayuda de la curia romana para protegerse de tales penas. Por ejemplo, Gregorio IX - a la vez que tomaba bajo su protección a la orden -negó la autorización para lanzar sentencias de excomunión o entredicho contra los alcantarinos ${ }^{12}$. Podemos encontrar disposiciones semejantes en muchas otras bulas ${ }^{13}$.

Los litigios y conflictos entre diocesanos y freires han dejado muchas más huellas documentales. Sin embargo, no podemos silenciar que también hubo, en algunas ocasiones, un espíritu de colaboración entre los alcantarinos y las diócesis. Los unía, sobre todo en los tiempos del gran empuje de la reconquista, el mismo afán por líbrar a la península ibérica del dominio islamita. También, desde las primeras bulas, se indicaba a los sanjulianistas que el crisma, los óleos, las consagraciones de los altares o de las basílicas y las ordenaciones de los clérigos las recibieran del obispo que ellos desearan ${ }^{14}$.

La sede apostólica comisionó a muchos obispos y dignidades diocesanas para mediar, intervenir, hacer cumplir..., las disposiciones papales: por ejemplo, a los arzobispos y miembros de los cabildos del reino de León ${ }^{15}$; al obispo, al deán y al tesorero de Salamanca ${ }^{16}$; al arzobispo de Compostela ${ }^{17}$; al obispo de Ávila ${ }^{18}$; al de Osma ${ }^{19}$; al arzobispo de Sevilla y a los obispos de Córdoba y Coria ${ }^{20}$; al obispo de Plasencia ${ }^{21}$, etc., ya que los ejemplos serían numerosísimos. Los prelados diocesanos actuaban en muchas ocasiones como mediadores o árbitros del papa en los asuntos concernientes a la orden del Pereiro-Alcántara. Así, la relación entre freires y obispos fue muy frecuente e inevitable, porque eran, excepto en algunos casos en los que fue precisa la

\footnotetext{
12 Bula del 31 de mayo de 1227: B) R.A.H., Col. Sal., I-19, ff. 202r-203r.

13 Bula del 18 de marzo de 1237: B) B.N., ms. 622, f. 195r-v. Bula del 31 de marzo de 1240: B) R.A.H., Col. Sal., I-19, f. 221 r-v. Bula de 1240, ed. A. de TORRES Y TAPIA, Op. cit. I, p. 299.

14 "Chrisma, vero, oleum sanctum, consecrationes altarium seu basilicarum, ordinationes clericorum, seu monachorum, qui ad sacros ordines fuerint promovendi, a quocumque malueritis catholico suscipiatis episcopo" (bula citada del 4 de abril de 1183).

is Bula citada del 31 de mayo de 1227.

16 Bula del 26 de enero de 1238, ed. I. J. de ORTEGA Y COTES, Bullarium de Alcantara, pp. 45-46.

17 Bula del 31 de marzo de 1240: B) R.A.H., Col. Sal., I-19, f. 221r-v.

IB Bula del 2 de septiembre de 1323: B) A.S.V., Reg. Aven. 19, f. 351v; C) A.S.V., Reg. Vat. 75, f. 183 r.

19 Bula del 2 de enero de 1340: B) A.S.V., Reg. Vat. 134, ff. 134r-135r.

20 Bula del 22 de enero de 1397: B) A.S.V., Reg. Aven. 303, f. 412v.

${ }^{21}$ Bula del 15 de enero de 1488; B) B.N., ms. 621, ff. 69r-71r, C) R.A.H., Col. Sal., I-19, ff, 281r-282v.
} 
intervención de los legados o emisarios pontificios, los colaboradores o mediadores habituales a los que acudía la curia romana para resolver los litigios.

Es necesario dedicar algunos párrafos a los conflictos entre la orden de $\mathrm{Al}$ cántara y la diócesis de Coria por las múltiples huellas que dichos litigios han dejado en la documentación pontificia. Para esclarecer con profundidad este tema es necesario localizar toda la documentación conservada al respecto en el Archivo Capitular de Coria ${ }^{22}$, además de los documentos papales. Nuestro propósito en este artículo, como en el título queda indicado, es mucho más modesto: tratar de iluminar algunos aspectos del problema basándonos en las bulas pontificias más significativas hasta ahora encontradas.

Debemos advertir previamente, para entender mejor estas conflictivas relaciones, que las dos partes contendientes tenían la conciencia de defender unos derechos que honestamente consideraban legítimos, muchas veces fundamentados en privilegios pontificios o reales contradictorios. Éstos se habían concedido a los dos bandos sin tener en cuenta la posible incompatibilidad entre sí.

Podemos distinguir, a grandes rasgos, dos períodos en las controversias entre los freires y los obispos caurienses. El primer período durante el siglo XIII, a partir de la década de los años treinta, que se cierra con dos sentencias arbitrales de María de Molina a comienzos del siglo XIV, centuria pacífica entre ambas instituciones. Los problemas no tardaron en resurgir durante el siglo $\mathrm{XV}$, adquiriendo un carácter crónico ${ }^{23}$. En este artículo sólo vamos a hacer referencia al primer período, ya que los conflictos del siglo XV no los podemos seguir a partir de la documentación pontificia hasta ahora disponible.

La primera bula pontificia que conservamos sobre las disputas del siglo XIII es una confirmación de un acuerdo, que hoy no conservamos, entre la

22 Dicha tarea ya está muy avanzada. Esperamos ofrecer al lector en un futuro próximo un estudio global, teniendo en cuenta todo tipo de documentación, sobre las relaciones alcantarino-caurienses durante la época medieval. Conocemos a dos autores que han trabajado sobre parte de dicha documentacion, siendo especialmente valioso el primer trabajo: P. RUBIO MERINO, "El obispado de Coria y la orden de Alcántara en los siglos XIII al XV a través de los fondos del Archivo Capitular de Coria", Anuario de Estudios Medievales XI (1981), pp. 731-748; S. BAY SANTANA, El obispado de Coria en los siglos XII-XV. Intereses y conflictos en su diócesis (memoria de licenciatura inédita), Cáceres 1983, pp. 136-182. J. L. Martín ha recogido en su colección documental algunos documentos muy interesantes al respecto, aunque en dicho archivo aún existen algunos inéditos que pueden aclarar las relaciones alcantarino-caurienses: J. L. MARTín MARTÍN, Documentación medieval de la Iglesia catedral de Coria, Salamanca 1989. También da datos de interés en su tesis doctoral inédita -especialmente desde el punto de vista canónico-, aunque no investigó en el archivo: F. CHAMORRO, La orden militar de Alcántara. Estudio histórico-jurílico, Madrid 1968, pp. 141-189.

23 P. RUBIO MERINo, Op. cit., p. 732.

Medievalia Híspanica

Hispania Sacra 50 (1998) 
orden de Alcántara y el obispo de Coria sobre rentas y otros derechos ${ }^{24}$. Sabemos que, durante el siglo XIII, los obispos y los freires trataron de delimitar sus respectivos derechos sobre un territorio reconquistado y con suficiente población como para hacer necesario un reparto de los frutos debidos por los fieles ${ }^{25}$.

En 1238 Gregorio IX ordenó al deán, maestrescuela y tesorero de Ciudad Rodrigo que actuara, mediante censuras de excomunión y entredicho, contra los que impidieran a la orden del Pereiro-Alcántara recibir posesiones en la ciudad y diócesis de Coria ${ }^{26}$.

En 1240 parece que se inició un fuerte pleito con don Sancho, obispo de Coria, ya que los acuerdos anteriores habían dejado cabos sueltos y dudas entre las partes. Torres y Tapia ${ }^{27}$ culpa al obispo cauriense, quien sin respetar la exención y libertades de la orden, lanzó censuras de excomunión contra los freiles alcantarinos. Éstos acudieron al amparo del papa. Gregorio IX emitió un rescripto dirigido al obispo de Idanha ${ }^{28}$ y a otras dignidades para que estudiaran este litigio y citaran a las partes en Ciudad Rodrigo. El obispo no compareció, aduciendo que Ciudad Rodrigo no era un lugar seguro, y decidió apelar al papa, quien de nuevo emitió otra bula ${ }^{29}$ dirigida al deán, arcediano y tesorero de Ciudad Rodrigo para que interviniesen en la causa. Por fin se logró reunir a las dos partes: los alcantarinos alegaron que el obispo no podía ser oído, ya que estaba excomulgado, y que la causa se debía remitir a los primeros jueces nombrados por el papa. El obispo, según el testimonio único y probablemente parcial del cronista Torres y Tapia ${ }^{30}$, actuó de forma maliciosa y contumaz, por lo que los jueces papales suspendieron al prelado de oficio y beneficio y le citaron en Ciudad Rodrigo, junto con el maestre de Alcántara, en un plazo de treinta días, bajo pena de excomunión si no comparecía. Según nuestro cronista, no sabemos cómo terminó este complicado litigio. Sin embargo, sí conservamos el texto completo de una bula de marzo de $1240^{31}$ que probablemente esté relacionada con este conflicto. Ante las quejas de los freiles, Gregorio IX dirigió un escrito al arzobispo de Compostela y a sus sufragáneos por el que prohibía a los oficiales episcopales decretar sentencias de excomu-

\footnotetext{
24 "Vobis sane significantibus, intelleximus quod olim inter vos ex parte una, et venerabilem fratrem nostrum episcopum cauriensem diocesanum vestrum ex altera, super quibusdam redditibus et rebus aliis questione suborta, cum eo tandem super his ad compositionem amicabilem devenistis" (bula del 8 de diciembre de 1232, ed. I. J. de ORTEGA Y COTES, Bullarium de Alcántara, p. 37).

25 S. BAY SANTANA, Op. cit., p. 138.

26 Bula del 18 de marzo de 1238: B) B.N., ms. 622, f. 205r-v; C) R.A.H., Col. Sal., I-19, f. 217r-v.

27 A. de TORRES Y TAPIA, Op. cit., I, pp. 299-302.

28 Bula de 1240, cit. A. de TORRES Y TAPIA, Op. cit., I, p. 299.

29 Bula de 1240, cit. A. de TORRES Y TAPIA, Op. cit., I, p. 299.

30 A. de TORRES Y TAPIA, Op. cit., pp. 301-302.

31 BuJa del 31 de marzo de 1240: B) R.A.H., Col. Sal., I-19, f. 221 r-v.
} 
nión, suspensión o entredicho contra aquéllos que mantuviesen negocios con la orden del Pereiro-Alcántara. Era una forma indirecta de presionar a los freires, a quienes los diocesanos trataban de minar sus bases económicas. Sin embargo, aquéllos consiguieron la protección apostólica y abortaron dicho intento.

En 1246 un nuevo documento pontificio ${ }^{32}$ nos informa de un nuevo enfrentamiento. El obispo cauriense recurrió al papa Inocencio $\mathrm{N}$ y se quejó de los abusos de la orden acerca de la fundación y edificación de oratorios e iglesias. Según el obispo, contravenían el indulto apostólico que tenía su iglesia y sus predecesores en la dignidad episcopal. Inocencio IV nombró al deán de Salamanca y al chantre y arcediano de Zamora jueces de dicho pleito. No tenemos noticias de cómo acabó este conflicto. Era una muestra más de la insuficiencia y limitación de los acuerdos entre alcantarinos y caurienses durante el siglo XIII.

Tenemos constancia de una nueva concordia firmada en $1257^{33}$ entre el obispo don Pedro (1253-60) y el maestre García Fernández (1254-84). El contenido de la concordia permite comprender los futuros malentendidos entre ambas partes. El obispo dio a los freires las iglesias de Cadalso, Gata, Salvaleón, Alcántara y Ceclavín - todas al norte del río Salor-, y el derecho de presentación de sus capellanes. Sin embargo, el obispo se reservaba la tercera parte de los diezmos de estas iglesias, el derecho de procuración y el pago anual del catedrático. En las iglesias sitas al sur del río Salor, los freires concedieron a los diocesanos el derecho de presentación de capellanes, la percepción de la sexma de los diezmos y el pago por los derechos de procuración y catedrático. Las dos partes tuvieron conciencia de la importancia de lo pactado, que fijaba los respectivos derechos y obligaciones, por lo que solicitaron la confirmación a la sede apostólica. En 1259 el papa Alejandro IV $^{34}$ confirmó los pactos entre las dos partes sobre jurisdicción, labor pastoral, diezmos y otros derechos. Ocho meses después el pontífice mandó al deán y arcediano de Coria que no permitieran el acoso sobre las posesiones que los alcantarinos tenían en la ciudad y diócesis de Coria ${ }^{35}$.

Durante el resto del siglo XIYI se firmaron más acuerdos entre las dos partes contendientes, pero no tenemos noticias de más intervenciones pontificias. Este período, de conflictos de carácter más bien global, se cerró con las sentencias arbitrales de la reina María de Molina ${ }^{36}$, que inauguraron un período de paz que, salvo raras excepciones, se prolongó durante todo el siglo XIV.

\footnotetext{
32 Bula del 26 de marzo de 1246, cit. A. de TORRES Y TAPIA, Op. cit., I, p. 311.

${ }^{33}$ P. RuBio Merino, Op. cit., p. 733. A. de TORRES Y TAPIA, Op. cit., I, pp. 360-363.

34 Bula del 9 de enero de 1259, ed. I. J. de ORTEGA Y COTES, Bullarium de Alcántara, p. 99.

35 Bula del 17 de septiembre de 1259: B) B.N., ms. 622, f. $11 \mathrm{r}-\mathrm{v}$.

36 Véase en: P. RUBIo MERINO, Op. cit., p. 737.
} 
Podemos concluir afirmando que ambas instituciones, diócesis de Coria y orden de Alcántara, tenían reconocidos, por la costumbre o por documentos escritos, derechos y funciones similares sobre el mismo territorio y sus habitantes. El afán por ejercerlos tenía que causar inevitablemente enfrentamientos entre las dos partes afectadas. Los litigios apenas eran acallados por los sucesivos compromisos, arbitrajes y concordias. En otros casos los documentos reflejaban la existencia de una situación mal definida desde el punto de vista administrativo, con la consiguiente falta de delimitación de competencias y con algunas vertientes contradictorias en los documentos, de manera que un mismo texto tenía distinta valoración para cada una de las dos partes. La santa sede estaba en una posición bastante comprometida y delicada, aunque contase con la ayuda de poderes eclesiásticos locales que conocían de forma más directa y cercana las controversias. Era muy complicado delimitar desde Roma, con meridiana claridad, los legítimos derechos de cada una de las instituciones en litigio.

\section{LA ORDEN DEL PEREIRO-ALCÁNTARA Y EL CÍSTER.}

Como otras órdenes militares, la orden del Pereiro-Alcántara estuvo sujeta no sólo al papado, sino también a otras instituciones religiosas como el Císter. Las primeras bulas concedidas a la orden no dicen nada sobre esta filiación, aunque parece que la misma data de finales del siglo XII. El primer documento papal conservado que afirma explícitamente la dependencia de la orden con respecto al Císter es una bula de Gregorio IX dirigida a los prelados de León para que defiendan al maestre y hermanos del Pereiro, pertenecientes a la orden cisterciense ${ }^{37}$. Desde este pontífice el "ritomello" repetido en Ia "directio" de las bulas medievales referidas a nuestra orden es siempre el mismo: "..., cisterciensis ordinis, cauriensis diocesis". No podemos, por consiguiente, retrotraer su filiación cisterciense a los más remotos orígenes de la orden, tal y como afirman cuatro bulas de Alejandro IV citando el testimonio del cardenal cisterciense Juan de Toledo, protector de la orden ${ }^{38}$. La curia romana en tiempos de Alejandro IV (1254-1261) no tenía una información fidedigna sobre este aspecto, a pesar de que quizá conservaran en los registros de bulas los documentos de Alejandro III y Lucio III, que no mencionaban que los hermanos del Pereiro fuesen filiales del Císter.

37 “..., dilecti filii magister et fratres militie de Pereyro, cisterciensis ordinis..." (Bula del 31 de mayo de 1227: B) R.A.H., Col. SaI., I-19, ff. 202r-203r).

38 Bula del 1 de diciembre de 1258: B) R.A.H., Col. Sal., I-19, ff. 228r-229r. Bula del 9 de enero de 1259: B) B.N., ms. 622, ff. 39r-40r; C) R.A.H., Col. Sal., I-19, ff. 239r-240r. Bula del 18 de marzo de 1259: B) B.N., ms. 622, ff. 21r-22r, C) R.A.H., Col. Sal., I-19, ff. 237r-238r. Bula del 29 de noviembre de 1259: B) R.A.H., Col. Sal., I-19, ff. 241r-242r. 
Los alcantarinos aprovecharon su condición cisterciense para solicitar a la sede apostólica las exenciones y privilegios, tanto espirituales como temporales, que ya disfrutaban los monjes blancos: exención del pago de procuraciones ${ }^{39}$; facultad para no pagar derechos de visita ${ }^{40}$; libertad para contribuir o no a cualquier colecta, subsidio, pedido..., como gozaban por concesión papal los abades del Císter ${ }^{41}$; el privilegio especial - junto con los calatravos- de no ser llamados a juicio a más de dos leguas de distancia de sus monasterios ${ }^{42}$; la exención del pago de colectas, subsidios y otras exacciones impuestas por la curia romana o sus emisarios ${ }^{43}$; el privilegio de que ningún prelado pudiese dictar sentencias de excomunión o entredicho contra los capellanes, familiares, benefactores $u$ otras personas relacionadas de algún modo con el monasterio del Pereiro-Alcántara ${ }^{44}$; y otros derechos cistercienses que el papa concedió a los alcantarinos durante la época medieval. En 1521 el papa León X extendió todos los privilegios y exenciones cistercienses a la orden de Alcántara ${ }^{45}$, con lo que ésta ya no tuvo necesidad de apélar a su filiación cisterciense ante la sede apostólica para que ésta reconociera los privilegios que por derecho le correspondían.

La santa sede encomendó la visita y corrección de la orden de Alcántara a los cistercienses. El sistema de filiación y visitas entre la casa-madre y las casas-hijas fue, junto con el capítulo general de la orden, la institución que preservó la unidad de todos los monasterios cistercienses. En la orden cisterciense, menos centralizada que Cluny, la abadía-madre debía visitar una vez al año a sus filiales, a las que podía corregir y castigar, si se apartaban de la regla y costumbres monásticas. Este sistema de visitas era un complemento perfecto de las reuniones periódicas del capítulo general cisterciense. Éste, al reunirse una sola vez al año y tratar de la infinidad de problemas de los numerosos monasterios de la orden, no podía asegurar el mantenimiento de la disciplina y la observancia de la regla en cada uno de los mismos. En cambio, el establecimiento de unas redes jerarquizadas de abadías-madres y abadías-hijas permitía una vigilancia y un control mucho más detallado.

La abadía-madre de los alcantarinos fue la de Morimond. Su abad fue el visitador ordinario de la orden de Alcántara durante la Edad Media, pero ello no fue óbice para que el papa nombrara otros visitadores cistercienses para ejercer la función de corrección y vigilancia sobre nuestra orden. Juan XXII, por

\footnotetext{
39 Bula del I de diciembre de 1258: B) R.A.H., Col. Sal., I-19, ff. 228r-229r.

40 Bula del 13 de diciembre de 1258: B) B.N., ms. 622, ff. 1r-2r.

41 Bula del 18 de diciembre de 1258, cit. A. de TORRES Y TAPIA, Op. cit., I, p. 375.

42 Bula del 3 de enero de 1259: B) R.A.H., Col. Sal., I-19, f. 236r-v.

43 Bula del 9 de enero de 1259: B) B.N., ms. 622, ff. 39r-40r, C) R.A.H., Col. Sal., J-19, ff. 239r249 r.

44 Bula del 29 de noviembre de 1259: B) R.A.H., Col. Sal., I-19, ff. 241r-242r.

45 Bula del 14 de junio de 1521, ed. I. J. de ORTEGA Y COTES, Bullarium de Alcántara, pp. 783-786.
} 
ejemplo, encomendó al abad cisterciense de Armenteira, diócesis de Compostela, la visita y corrección de la orden de Alcántara y su maestre hasta que se resolviese el cisma en la orden de Calatrava ${ }^{46}$. Pío II confirmó al abad de Morimond como visitador y reformador de las órdenes de Alcántara, Montesa, Avis y la milicia de Cristo ${ }^{47}$. Alejandro VI en 1494 confirmó las mismas disposiciones $^{48}$. En 1489 Inocencio VIII ordenó a don Pedro, abad de Claraval, la visita de las órdenes de Alcántara, Calatrava y Montesa, con la autoridad del capítulo general del Císter y del abad de Morimond ${ }^{49}$. Dicha visita se realizó a comienzos del mes de diciembre de $1492^{50}$. El romano pontífice, además, protegió a los alcantarinos frente a los abusos de los obispos diocesanos, que pretendían visitar y corregir la orden haciendo caso omiso de su filiación cisterciense: por ejemplo, frente al obispo de Plasencia y los cabildos de Coria y Plasencia ${ }^{51}$.

\section{LA ORDEN DEL PEREIRO-ALCÁNTARA Y' O'TRAS ÓRDENES MILITARES.}

A la luz de la documentación papal, podemos ofrecer algunos datos muy interesantes sobre las relaciones de colaboración y las disputas entre la orden del Pereiro-Alcántara y otras órdenes militares que tuvieron diversas encomiendas en los reinos de Castilla y León, tanto hispanas como internacionales.

En primer lugar, debemos ocuparnos de las relaciones de nuestra orden con la de Calatrava, ambas - como sabemos- de filiación cisterciense. La sede apostólica las consideraba como órdenes hermanadas o subordinadas la una a la otra a la hora de extender algunos privilegios cistercienses a las dos ${ }^{52}$. La relación entre la orden de San Julián del Pereiro y la orden de Calatrava antes de 1218 es un problema muy difícil de dilucidar. En 1187 el papa Gregorio VIII, según la lectura de los autores del bulario calatravo del siglo XVIII, confirmó las posesiones de la orden de Calatrava, e incluyó entre ellas el Pereiro,

46 “.... visitandi et comigendi prefatam militian de Alcantara, loca et personas ipsius, tam in capite quam in membris suis, corrigendi quoque et puniendi Sugerium Petri, magistrum militie antedicte, si necesse fuerit et resignationem huiusmodi sui regiminis recipiendi, aliaque omnia in his et circa ea faciendi..." (Bula del 1 de octubre de 1331: B) A.S.V., Reg. Aven. 40, f. 11v; C) A.S.V., Reg. Vat. 101, f. $57 \mathrm{r}$ )

47 Bula del 26 de julio de 1459: B) A.S.V., Reg. Vat. 501, ff. 329v-330r.

48 Bula del 8 de enero de 1494: B) A.S.V., Reg. Suppl. 984, f. 107r-v.

49 Bula de 1489, cit. A. de TORRES Y TAPIA, Op. cit., Il, p. 549.

50 A. de TORRES Y TAPIA, Op. cit., II, pp. 549-553.

sI Bula del 23 de enero de 1437: B) B.N., ms. 622, ff. 133r-134v.

52 Bula del 31 de enero de 1259, ed. I. J. de ORTEGA Y COTES, Bullarium de Alcántara, p. 606. Bula del 12 de febrero de 1259; B) R.A.H., Col. Sal., I-19, f. 236r-v. 
situado entre Ciudad Rodrigo y Troncoso ${ }^{53}$. Sorprendentemente en los privilegios papales coleccionados por Juan Calderón de Robles ${ }^{54}$ y en una copia de la colección Salazar y Castro ${ }^{55}$ no constan las palabras: "in quibus haec propriis duximus exprimenda vocabulis: (...) El Pererii, inter Civitatem Rodrigo et Troncoso, cum omnibus possessionibus et pertinentiis suis", que sí aparecen en el bulario calatravo, como leemos en la nota correspondiente. Calderón de Robles y la colección Salazar y Castro transcriben toda la bula de Gregorio VIII, con los mismos términos que los autores del bulario calatravo, pero sin incluir la larga lista de posesiones ${ }^{56}$. ¿ Se trata de una interpolación de los calatravos o de una supresión de los alcantarinos ? No conservamos ni la bula original ni el registro correspondiente en el Archivo Vaticano, sin embargo, parece que probablemente fue una supresión realizada por los alcantarinos. En 1199 Inocencio III confirmó a la orden de Calatrava sus posesiones, entre las que se incluía: "Pererii, inter Civitatem Roderici et Troncoso". En este caso Calderón de Robles ${ }^{57}$ y la colècción Salazar y Castro ${ }^{58}$, que nos han transmitido la bula de 1199, coinciden en el mismo texto, sin supresión de la lista de posesiones, como ocurría en la bula de Gregorio VIII. Además, conservamos una copia del registro de la bula de 1199 en el Archivo Vaticano ${ }^{59}$ que, aunque no sea un registro original, parece que sí es una copia fidedigna posterior. En este caso el cronista Torres y Tapia, quien defiende a toda costa la independencia del Pereiro con respecto a Calatrava y que no había mencionado la bula

53 "Preterea quascumque possessiones, quecumque bona, eadem domus impresentiarum iuste et canonice possidet, aut in futurum concessione pontificurn, largitione regum, vel principum, oblatione fidelium, seu aliis iustis modis, prestante domino poterit adipisci, firma vobis, vestrisque successoribus, et illibata permaneant in quibus haec propriis duximus exprimenda vocabulis: (...) El Pererii, inter Civitatem Rodrigo et Troncoso, cum omnibus possessionibus et pertinentiis suis..." (Bula del 4 de noviembre de 1187, ed. I. J. de ORTEGA Y COTES; J. F. Ál VAREZ DE BAQUEDANO; P. de ORTEGa ZúNIIGA Y ARANDA, Bullarium ordinis militiae de Calatrava, Madrid 1761 (reimpr., Barcelona 1981), pp. 22-25).

54 J. CALDERón DE RoBles, Privilegia selectiora Militiae Sancti luliani de Pereiro (hodie de Al cántara) Cisterciensis ordinis, a Summis Pontificibus hactenus concessa, Madrid 1627, pp. 100-103.

55 B) R.A.H., Col. Sal., I-19, ff. 323r-325v.

56 Además, las copias de la bula tienen un desconcertante encabezarniento, tanto en Calderón de Robles como en la colección Salazar y Castro: "Gregorius episcopus, servus servorum Dei, dilectis filiis Nunnoni, magistri, et fratribus de Calatrava, tam presentibus quam futuris, secundum ordinem cisterciensis fratrum viventibus Innocentius pp. III (sic). Quotiens a nobis..." (J. CALDERÓN DE ROBLES, Op. cit., p. 100; R.A.H., Col. Sal. I-19, f. 323r). En cambio, en la versión del bulario - procedente del archivo de Calatrava - se lee: "..., fratrum viventibus in perpetuum. Quotiens a nobis..." (I. J. de ORTEGA Y COTES, Bullarium de Calatrava, p. 22). Probablemente Calderón y Salazar y Castro están mezclando los textos de la bula de 1187 de Gregorio VIII con los de la de 1199 de Inocencio III, en la que este papa confirmaba a la orden de Calatrava sus posesiones.

57 J. CALDERón DE RoBles, Op. cit., pp. 94-100.

58 B) R.A.H., Col. Sal., I-19, ff. 317r-321v.

59 Bula del 28 de abril de 1199: B) A.S.V., Armarium XXXIX, vol. I, ff. 104r-107r.

Medievalia Hispanica

Hispania Sacra 50 (1998) 
de Gregorio VIII, sí se hace eco del texto de Inocencio III y de la inclusión del Pereiro entre las posesiones calatravas ${ }^{60}$. Sin embargo, dicho cronista niega la veracidad de la bula de Inocencio III de 1199, al igual que otros documentos "sospechosos" que están en el archivo del convento de Calatrava, por incluir entre las posesiones calatravas el Pereiro y Avis ${ }^{61}$. ¿Cómo explicar la inclusión del Pereiro entre las posesiones de Calatrava a finales del siglo XII? Nosotros no encontramos una respuesta plenamente satisfactoria. Partimos de la premisa de que es probable la identificación entre "el Pererii" y San Julián del Pereiro, sin embargo, sería posible dudar de dicha identificación. Si aceptamos la identificación podemos preguntarnos por qué no se incluyen el resto de posesiones de los sanjulianistas: Raigada, Villar de Turpino, Ferrera, etc. Todos los documentos conservados de esta época muestran que los sanjulianistas no pertenecían a la orden de Calatrava, sino que fueron una institución claramente diferenciada. Por tanto, no es muy inteligible incluir El Pereiro entre las posesiones de la orden de Calatrava. $O^{\prime}$ Callaghan ofrece una posible solución al problema. Según este autor ${ }^{62}$, antes de la publicación de la bula de Gregorio VIII las dos órdenes debieron concertar alguna forma de asociación. Probablemente cuando Calatrava aceptó las costumbres del Císter y reconoció el derecho de visita y de nombramiento del prior por parte del abad de Morimond, San Julián del Pereiro debió aceptar las costumbres de Calatrava y a su maestre como visitador. Pero, ninguno de los documentos conservados sugiere dicha asociación, a la que debía haberse hecho mención en el acuerdo de 1218 por el que Calatrava cedía a los sanjulianistas Alcántara y todas las posesiones y privilegios que posefan en el reino de León, además de reconocer al maestre del Pereiro el derecho a estar presente en la elección del maestre calatravo; a cambio, a este último se le otorgaba el derecho de visita y reforma de los sanjulianistas, de acuerdo con la orden del Císter ${ }^{63}$. Si aceptamos la hipótesis de $O^{\prime}$ Callaghan el acuerdo de 1218 no se entiende bien, ya que en el mismo se otorga al maestre de Calatrava la facultad para visitar la orden del PereiroAlcántara. Según la hipótesis de este autor, tal facultad ya existía desde bastante tiempo antes. Lo que sugieren los términos del acuerdo de 1218 es que

60 A. de TORRES Y TAPIA, Op. cil., I, p. 513.

61 "Siendo esto así, bien se conoce la gran razón que hay de dudar de la certidumbre de la bula que tiene la orden de Calatrava y anda en el bulario de la de Alcántara, pues están expresados en ella por bienes propios los que claramente consta eran agenos" (A. de TORRES Y TAPIA, Op. cit., l, p. 14). Advirtamos que cuando Torres y Tapia se refiere al bulario de Alcántara está haciendo referencia a la recopilación de privilegios papales de Calderón de Robles, quien entre las páginas 94 y 100 inserta esta bula de Inocencio III.

$62 \mathrm{~J}$. F. O'CALlaghaN, "The Foundation of the Order of Alcantara, 1176-1218", Catholic Historical Review 42 (1962). pp. 480-481.

${ }^{63}$ Acuerdo del 16 de julio de 1218: B) R.A.H., Col. Sal., I-37, f. 140r-v. 
dicha facultad era una nueva concesión hecha a cambio de conceder las posesiones leonesas de la orden de Calatrava. En definitiva, explicar la inclusión del Pereiro entre las posesiones calatravas a fines del siglo XII parece casi imposible, si no se encuentran más documentos que puedan arrojar luz sobre este tema. A nuestro modo de ver, ninguna de las hipotesis formuladas por la historiografia resulta satisfactoria.

Ya hernos hecho mención del importante acuerdo de julio de 1218 entre Calatrava y San Julián del Pereiro, a partir del cual nuestra orden iba a adoptar la denominación de orden de Alcántara, por ser dicha villa la principal posesión cédida por los calatravos a los sanjulianistas y donde éstos iban a instalar su nuevo convento central. Dicho acuerdo impulsó sobremanera el desarrollo de la orden del Pereiro, aun a costa de suponer cierta sujección a Calatrava. Con los bienes calatravos del reino de León la orden de Alcántara quedó afianzada como una orden militar de cierta entidad.

Del decisivo acuerdo de 1218 arranca la gran polémica sobre la sujección o no de los alcantarinos a Calatrava. Los cronistas, a veces forzando el sentido original de las palabras, valoraron de forma muy diferente este importante pacto. Rades y Andrada, a nuestro modo de ver con cierta parcialidad - logica en un freire calatravo del siglo XVI--, consideró que este acuerdo significó la unión e incorporación de la orden del Pereiro con la de Calatrava, tras el cual los freires de cada orden "quedaron en tanta conformidad y hermandad, como si de muy atrás fueran de una mesma orden"64. Esta última afirmación es exagerada, ya que sí hubo litigios ulteriores entre las dos órdenes referidos a la sujección de una a otra. En cambio, pensamos que Rades sí tiene razón al aseverar que los freires del Pereiro quedaron en cierta manera sujetos al maestre de Calatrava para ser visitados ${ }^{65}$. Torres y Tapia ${ }^{66}$ valoró la enorme trascendencia de este acuerdo, que fue la "piedra de escándalo" que ocasionó la gran polémica sobre la precedencia de una $u$ otra orden. Con pasión y parcialidad - también comprensible, aunque no justificable, en un prior alcantarino del siglo XVII - trató por todos los medios de negar la sujección de la orden de Alcántara a la de Calatrava. Para él los freires alcantarinos no quedaron sujetos a los calatravos por el acuerdo de 1218, sino sólo a su maestre, y no en todas las cosas. Insistió en que la consideración de la orden de Alcántara como una filiación de la orden de Calatrava era una vana creencia "sin fundamento ni razón jurídica". Afirmó, sin base firme, que la orden de Calatrava no debía preceder a la de Alcántara, ya que ésta era más antigua. Recalcó que por este

\footnotetext{
64 F, de RADES Y ANDRADA, Chronica de las tres órdenes y Cavallerías de Santiago, Calatrava y Alcántara, Toledo 1572 (reimpr., Barcelona 1980), crónica de Alcántara, f. 6v.

65 F. de RADES Y ANDRADA, Op. cit., f. 7r.

66 A. de TORRES Y TAPIA, Op. cit., I, pp. 184-208.
}

Medievalia Hispanica

Hispania Sacra 50 (1998) 
acuerdo sólo se concedió al maestre calatravo el derecho de visitar a los alcantarinos, según la orden del Císter, orden a la que pertenecían alcantarinos y calatravos antes de firmar el acuerdo; y que fue "gravamen no pequeño" que la orden de Calatrava aceptase la presencia del maestre del Pereiro en sus elecciones al maestrazgo. Este cronista contradice de forma constante a Rades, al que acusa de afirmar sin probar y de valerse sólo de conjeturas. Incluso Torres y Tapia reconoce su propio apasionamiento, que justifica con la excusa de que los hijos de Calatrava le han provocado ${ }^{67}$.

Hay que llamar la atención sobre una interesante bula de Honorio III, fechada en 1224 y de cuya veracidad no se puede dudar al conservarse en los registros de bulas del Archivo Vaticano ${ }^{68}$, que nos informa de que algunos freires sanjulianistas se quejaron del despotismo del maestre de Calatrava, quien citó a los freires del Pereiro ante el obispo zamorano y otros jueces, y allí les exigió obediencia. Los jueces dictaminaron que los sanjulianistas no debían obedecer al maestre de Calatrava. Sin embargo, éste último utilizó al prior del Pereiro para convencer al maestre de la misma orden que su obligación era obedecer al maestre calatravo, en contra de la sentencia de los jueces apostólicos. Los freiles sanjulianistas descontentos apelaron al papa porque se les había dejado sin medios para continuar con este pleito. Honorio III ordenó al obispo, deán y tesorero de Idanha - a quienes iba dirigida la bula- que conminaran al maestre de Calatrava a reconocer la libertad de los sanjulianistas; si ello no se consiguiera deberían comparecer todas las partes, con sus procuradores, ante el papa para dirimir el pleito ${ }^{69}$. Derek Lomax arguye esta bula, entre otras cosas, como una demostración de que la "unión" de las órdenes precedió al convenio de 1218, ya que el obispo de Zamora al que se refiere Ia bula debe de ser don Martín Arias (1193-1217) ${ }^{70}$. Según este mismo autor, aunque don Martín dio sentencia contra Calatrava, se ve que en algún momento de su episcopado el maestre calatravo creyó tener un derecho y una autoridad sobre la orden del Pereiro bastante plausibles como para ser confir-

${ }^{67}$ A. de TORRES Y TAPIA, Op. cit., I, p. 208.

68 Bula del 15 de octubre de 1224: B) A.S.V., Reg. Vat. 13, ff. 6v-7r.

69 "(...) per apostolica scripta mandamus: quod magistrum et fratres de Calatrava ut eum quem prefecerunt domui antedicte ad suum consortium revocantes, domum jpsam gaudere permittant debita libertate moncatis prudenter et efficaciter inducatis. Qui si de iure forsitan confidentes monitis acquiescere non curaverint, eis et fratribus dicte domus ac etiam diocesano loci forte ius aliquid sibi vendicat in eadem prefigatis auctoritate nostra terminum competentem quo per procuratores idoneos cum instrumentis ad hoc negotium pertinentibus si qua forsitan habeant, compareant coram nobis exhibjturi et recepturi super his quod ordo dictaverit rationis, fratribus vero ipsius domus faciatis de bonis eiusdem expensas ad prosecutionem huiusmodi negotii necessarias ministrari" (bula citada del 15 de octubre de 1224).

${ }^{70}$ D. LoMAX, "Las milicias cistercienses en el reino de León", Hispania 23 (1963), pp. 33-34. 
mada por jueces pontificios. Reconoce que la razón de creer esto no es muy evidente: ni los pergaminos ni los cartularios de Calatrava se refieren a estos pleitos contra el Pereiro. Lomax sólo aduce la bula, citada anteriormente, de Gregorio VIII en 1187, confirmada posteriormente en 1199 y 1214. Para este investigador parece evidente que el maestre de Calatrava poseía ciertos derechos sobre la orden del Pereiro ya en 1187, y que los retuvo hasta perder el pleito ante don Martín entre 1193 y 1217.

Nosotros dudamos de esa supuesta evidencia y, además, consideramos inapropiado hablar de "unión" entre las dos órdenes. Tampoco nos parece que la identificación del obispo zamorano de la bula con don Martín Arias esté demostrada. Lomax cierra su interesante artículo con la siguiente afirmación: después de 1225 no se trató de independizar a Alcántara hasta el siglo XVI ${ }^{71}$. Para este autor la "afiliación" a Calatrava brindó a los freiles leoneses los privilegios espirituales y temporales del Císter, la posibilidad de promoción de sus maestres y la de obtener heredades, además de en León, en Castilla, Andalucía y Murcia. Para Lomax, hacia mediados del siglo XIII, la memoria de los freiles del Pereiro que protestaron contra la "union" de 1218 se había perdido en todas partes fuera del Archivo del Vaticano. Nosotros, en cambio, no creemos demostrable que se perdiera la memoria de las protestas contra la "unión" de 1218 - para nosotros acuerdo de 1218-, ya que éstas rebrotaron en el siglo XIV. La afirmación más prudente es que permanece indemostrable tanto la pérdida como el mantenimiento de esa memoria, debido a la escasez de documentos. Pero la hipótesis de que se mantenía la conciencia de incomodidad respecto a la sujección de Alcántara a Calatrava creemos que es más probable que la otra hipótesis, debido a la reaparición de las protestas en el siglo XIV con motivo de las visitas del maestre de Calatrava a la orden de Alcántara ${ }^{72}$.

Conservamos otra bula interesante de 1238 por la que Gregorio IX, a petición de los freires del Pereiro-Alcántara, les confirmaba las posesiones y otras cosas que habían recibido de la orden de Calatrava en el reino de León ${ }^{73}$. Posiblemente - es una hipótesis difícil de verificar por los pocos documentos conservados- - la orden del Pereiro-Alcántara pretendía proteger las posesiones del reino de León frente a las pretensiones hegemónicas de los calatravos, que no se resignaban a perder el control sobre sus antiguas posesiones leonesas.

En 1331 Juan XXII encomendó al abad del monasterio de Armenteira la visita y corrección de las personas y lugares de la orden de Alcántara hasta que se resolviera el cisma entre los dos pretendientes al maestrazgo de la orden de

\footnotetext{
71 D. LOMAX, "Las milicias cistercienses...", Op. cit., p. 38.

72 Nos referimos a las visitas del 19 de enero de 1318 y del 26 de mayo de 1337: vid. I. J. de ORTEGA Y COTES, Bullarium de Calatrava, pp. 173-176 y 193-194.

${ }^{73}$ Bula del 31 de marzo de 1238: B) R.A.H., Col. Sal., I-19, f. 220r-v.
} 
Calatrava, a la que los alcantarinos estaban "sujetos"74. Está claro que el papa reconocía la facultad de visita al maestre de Calatrava y la sujección de los alcantarinos a los calatravos. No se puede dudar de la autenticidad de dicha bula, ya que conservamos su registro original en los "Registra Avenionensia" del Archivo Vaticano. El argumento de defensa de los que mantienen que los alcantarinos no estaban sujetos a la orden de Calatrava sólo puede basarse en el supuesto desconocimiento de la sede apostólica sobre el incumplimiento del acuerdo de 1218: el maestre de Alcántara durante la época medieval no había sido llamado para intervenir en la elección del maestre de Calatrava, por tanto, los otros puntos del acuerdo, entre ellos el derecho de visita y corrección del maestre calatravo, tampoco estaban vigentes.

En conclusión, la documentación pontificia es muy necesaria para esclarecer las relaciones entre alcantarinos y calatravos, pero no es suficiente para emitir un juicio final sobre la supuesta filiación y dependencia de la orden de Alcántara con respecto a la orden de Calatrava durante toda la época medieval. El rastreo de documentación alcantarina que se está realizando en diversos archivos, bibliotecas e instituciones peninsulares para componer la colección diplomática medieval de la orden de Alcántara completará muy pronto los datos que aquí ofrecemos, y permitirá emitir conclusiones firmes sobre este enrevesado asunto.

Asimismo la documentación pontificia nos da información muy valiosa sobre las relaciones de la orden de Alcántara con dos órdenes militares internacionales: los templarios y los hospitalarios.

Fue con la orden del Temple, entre todas las órdenes militares, con quien mantuvieron las relaciones más tensas hasta comienzos del siglo XIV. Las controversias alcanzaron su punto culminante en la lucha abierta de 1308 y sólo terminaron con la disolución de los templarios en el concilio de Vienne de 1311-1312, que permitió a la orden de Alcántara engrosar sus posesiones a costa de los bienes templarios, pero que abrió otros frentes de conflicto con otras ordenes militares, principalmente con los hospitalarios.

$\mathrm{La}$ disputa entre alcantarinos y templarios por Ronda ha dejado algunas huellas en la documentación pontificia. La fase del conflicto más acalorada sobre dicha villa, situada a orillas del Tajo y próxima a Montalbán y Talavera, parece ser que tuvo su inicio en 1235, aunque se remontaba a algunos años

74 "Sane ad audientiam apostolatus nostri pervenit, quod militia de Alcántara, cisterciensis ordinis, ordini calatravensi subiecta existit, quoad visitationem et correctionem, tam in capite quam in membris, sernel annis singulis facienda; verum quia super magistratu dicti ordinis calatravensis est dissencio inter duos, militia de Alcántara predicta per tempus dissensionis huiusmodi, nec in capite nec in membris, ipsis extitit visitata" (Bula del 1 de octubre de 1331: B) A.S.V., Reg. Aven. 40, f. $11 \mathrm{v}$; C) A.S.V., Reg. Vat. 101, f. 57r). 
antes. Dicha localidad pertenecía a nuestra orden, pero después pasó a manos templarias. La orden del Pereiro-Alcántara no se resignó a aceptar la pérdida de Ronda. Tenemos noticia documental de que los alcantarinos, con el apoyo de los calatravos, acudieron a la sede apostólica con la queja de que algunos bienes y posesiones de Ronda habían sido expoliados injustamente por los templarios $^{75}$. Gregorio IX ordenó al chantre, al tesorero y a un canonigo de Talavera que, convocadas y oídas las partes, administraran justicia y resolvieran el litigio. Pero esta controversia se complicó considerablemente en los años sucesivos. Intervinieron en ella, además, varias autoridades de la diócesis de Ciudad Rodrigo y el prior del convento de la Caridad ${ }^{76}$. Los alcantarinos reclamaban Ronda y sus frutos, además de cuarenta y dos mil cabezas de ganado ovino y otras reivindicaciones. Hubo varias comparecencias ante los jueces delegados, pero el litigio fue empeorando. Incluso dos freiles templarios, Miguel Navarro y Pelayo Muñiz, se resistieron junto con un grupo de musulmanes y cristianos armados que habían reclutado. La postura de los templarios cada vez era más inflexible, por lo que se procedió a excomulgarlos y a fallar a favor de la orden de Alcántara. Conservamos el largo informe del chantre y tesorero de Talavera, jueces delegados por el papa, al arzobispo compostelano sobre este controvertido litigio. Estos dos jueces le solicitaron, finalmente, que hiciera pública la sentencia de excomunión en su diócesis contra el maestre del Temple en España ${ }^{77}$. El pleito, según Torres y $\mathrm{Tapia}^{78}$, continu $\delta$, lo cual parece cierto, aunque hoy no conservamos los documentos que cita Torres y Tapia. Sin embargo, hay que tener en cuenta que este cronista es parte interesada al atribuir a los templarios tergiversación del litigio y "siniestra relación" de lo ocurrido $^{79}$. Por consiguiente, su testimonio hay que analizarlo con mucha precaución. Según este cronista, los templarios acudieron a Inocencio IV en demanda de sus solicitudes. Este pontífice mandó al deán y al arcediano de Toro, además del maestrescuela de Zamora, que prosiguiesen y terminasen la cau$\mathrm{sa}^{80}$. La nueva comisión pontificia, siempre según el testimonio único de Torres y Tapia, citó a las dos partes el 2 de enero de $1245^{8}$. Los templarios solicitaron la revocación de la sentencia sobre Ronda favorable a los alcantarinos

\footnotetext{
75 "Dilecti filii de Alcántara et de Pirario, magister et fratres calatravensis, cisterciensis ordinis, nobis conquerendo mostrarunt quod magister et fratres militie Templi in Hispania, ipsos quibusdam animalibus, possessionibus et rebus aliis ad eos communiter pertinentibus, contra iustitiam spoliarunt" (bula del 28 de marzo de 1235, ed. I. J. de ORTEGA Y COTES, Bullarium de Alcántara, pp. 51-52).

${ }^{76}$ Documento del 31 de marzo de 1243, ed. I. J. de ORTEGA Y COTES, Bullarium de Alcántara, p. 52 .

77 Documento citado del 31 de marzo de 1243.

${ }^{78}$ A. de TORRES Y TAPIA, Op. cit., I, pp. 308-309.

79 A. de TORRES Y TAPIA, Op. cit., I, p. 308.

${ }^{80}$ Bula del 27 de abril de 1244, cit. A. de TORRES Y TAPIA, Op. cit., I, p. 308.

81 A. de TORRES Y TAPIA, Op. cit., I, p. 309.

Medievalia Hispanica

Hispania Sacra 50 (1998)
} 
y la absolución de la excomunión contra su maestre, pero la orden de Alcántara alegó que la información dada al pontífice por la orden del Temple era falsa. Hubo nuevas citaciones a las dos partes y sus procuradores sin que se llegase a un acuerdo: en agosto de 1245, el 26 de marzo de 1254, etc. EI litigio, según Torres y Tapia $^{82}$ y A. Ballesteros ${ }^{83}$, fue alargandose sin concluir, a pesar del nombramiento de nuevas comisiones arbitrales y de la intervención real y papal. Los templarios se presentaron ante Alejandro IV y éste, según Torres y Tapia, emitió una bula para que los jueces correspondientes citaran a las partes contendientes y fijar así una vista definitiva ante el papa ${ }^{84}$. Se nombraron nuevos procuradores, hubo nuevas incomparecencias, etc. No conocemos cómo terminó este larguísimo y complicado litigio, ya que no hemos encontrado en los Registros Vaticanos ninguna mención. Ni siquiera Torres y Tapia, quien tuvo a su disposición el archivo central de la orden de Alcántara, sabe dar razón del final del mismo. Sólo aventura que probablemente a los alcantarinos no se les restituyó Ronda ${ }^{85}$.

A comienzos del siglo XIV se produjo el proceso y subsiguiente supresión de los templarios en el concilio de Vienne (1311 1312). La disolución de éstos fue el origen en Castilla de disputas entre las órdenes militares hispanas y la orden de San Juan de Jerusalén por las antiguas posesiones templarias. Para Castilla el papa Juan XXII había decretado la entrega de los bienes a la orden de San Juan de Jerusalén o del Hospital, ya que la minoría de edad de Alfonso $\mathrm{XI}$ hizo que los gobemantes castellanos no se preocuparan de negociar con el papa la fundación de una nueva orden militar que, como en Aragón y Portugal, heredara los bienes de los templarios. Sin embargo, tenemos noticias de que algunas posesiones y villas templarias fueron ocupadas por las ordenes de Santiago, Calatrava y Alcántara. Ante ello los sanjuanistas presentaron sus reclamaciones al papa. Juan XXII emitió dos extensas bulas en mayo de 1320, cuyos registros se conservan hoy en el Archivo Vaticano, a favor de los hospitalarios. En la primera bula notificaba a la orden de Alcántara, al igual que hizo en otras bulas con Santiago y Calatrava, que los bienes del Temple en Castilla y León habían sido cedidos a la orden de San Juan de Jerusalén ${ }^{86}$. En la segunda ordenaba al arzobispo de Compostela y a los obispos de Lugo y Córdoba que instaran a los maestres y freires de las ordenes de Santiago, $\mathrm{Ca}$ -

\footnotetext{
82 A. de TORRES Y TAPIA, Op. cit., I, pp. 352-354.

83 A. BALlesteros BeRETTA, El itinerario de Alfonso el Sabio, Madrid 1955, p. 51

84 Bula del 9 de septiembre de 1255, cit. A. de TORRES Y TAPIA, Op. cit., I, p. 353.

85 "No sabré decir el fin que tubo en Roma pleyto tan ren̂ido, porque no hay más razón de él en el archivo del convento de Alcántara; cierto es que a esta orden no se le restituyo el lugar de Ronda, pues no se halla hoy con él, si ya no le cambió con otros algunos bienes de que no hay memoria" (A. de TORRES Y TAPIA, Op. cit., I, p. 354).

86 Bula del 1 de mayo de 1320: B) A.S.V., Reg. Vat. 70, ff. 389r-390v.
} 
latrava y Alcántara a entregar los bienes de la extinta orden templaria a los sanjuanistas ${ }^{87}$. En septiembre de 1320 el papa, ante el incumplimiento de sus ordenanzas, mandó a la reina doña María de Castilla ayudar a la orden del Hospital a recuperar los bienes templarios que estaban en poder de los santiaguistas, calatravos y alcantarinos ${ }^{88}$.

En 1323 Juan XXII encomendó al obispo de Ávila el pleito que mantenían alcantarinos y hospitalarios por los castillos templarios de Garlitos, Capilla y Almorchón ${ }^{89}$. El rey Fernando IV de Castilla había cedido a los alcantarinos estas posesiones templarias. Sin embargo, las mismas fueron reclamadas posteriormente por los hospitalarios. Gracias a Torres y Tapia ${ }^{90}$ conservamos una apelación de Suero Pérez, maestre de la orden de Alcántara, ante el papa en la que se quejaba de la actuación de Lope Suárez, freire sanjuanista, quien reclamaba para su orden los bienes templarios en Castilla y León. Probablemente en el curso de la controversia se lanzó sentencia de excomunión contra el maestre Suero Pérez por tener ocupados estos lugares. Una bula de Benedicto XII al obispo de Palencia ordenaba absolver de la excomunión a Suero Pérez por tener ocupados castillos templarios que pertenecían a la orden de San Juan de Jerusalén ${ }^{91}$.

En 1324 el papa había rogado, una vez más, al arzobispo compostelano que mediase en el conflicto entre las órdenes de Calatrava, Alcántara y San Juan de Jerusalén por los antiguos bienes templarios ${ }^{92}$. Pero los esfuerzos del papado por hacer cumplir sus disposiciones sobre el destino de los bienes del Temple en Castilla fueron particularmente infructuosos, ya que buena parte de las posesiones templarias fueron a parar a manos de la corona, la nobleza y las órdenes de Santiago y Alcántara.

\section{LA ORDEN DE ALCÁNTARA Y LA MONARQUIA.}

La monarquía desde el principio estuvo interesada en controlar las órdenes militares para utilizarlas en su favor y consolidar la preeminencia regia en el

\footnotetext{
87 Bula del 1 de mayo de 1320: B) A.S.V., Reg. Vat. 70, ff. 390v-391r.

${ }^{88}$ Bula del 17 de septiembre de 1320: B) A.S.V., Reg. Aven. 14, f. 71r-v; C) A.S.V., Reg. Vat. 71, f. 95 r.

${ }^{89}$ Bula del 2 de septiembre de 1323: B) A.S.V., Reg. Aven. 19, f. 353v; C) A.S.V., Reg. Vat. 75 , f. 183 r.

90 A. de TORRES Y TAPIA, Op. cit., I, pp. 522-524.

91 Bula del 6 de mayo de 1335: B) A.S.V., Reg. Aven. 48, ff. 205v-206r; C) A.S.V., Reg. Vat. 119 , ff. 141 v-142r; D) A.S.V., Reg. Vat. 130, ff. 38r-39r. $152 \mathrm{v}$.

92 Bula del 25 de enero de 1324: B) A.S.V., Reg. Aven. 20, f. 273v; C) A.S.V., Reg. Vat. 76, f.

Medievalia Hispanica

Hispania Sacra 50 (1998)
} 
reino. Conforme avanzaron los tiempos medievales este interés fue creciendo cada vez más, ya que estas instituciones fueron adquiriendo un poder político, económico, militar y territorial muy considerable.

La orden de Alcántara no fue una excepción, aunque su poderío fuera menor que las órdenes de Santiago o Calatrava. Este proceso se plasmó en diversos sistemas transitorios de control y absorción de las órdenes militares: juramento de fidelidad vasallática de los maestres al rey, presiones para elegir maestres favorables, imposición regia de los candidatos, derecho al nombramiento de maestres, administración temporal del maestrazgo, etc., hasta que culminó con la anexión a finales del siglo XV de los tres maestrazgos a la corona: primero Calatrava, después Santiago $\mathrm{y}$, por último y con unas peculiaridades diferenciadas, Alcántara.

Los freiles de Alcántara lograron, aunque en escasas ocasiones, que el papado los apoyara frente a las arbitrariedades de la monarquía. Benedicto XII, por ejemplo, protegió a la orden de los excesos del rey portugués, que había producido daños a los alcantarinos ${ }^{93}$ y ocupado sus bienes ${ }^{94}$. Asimismo, este pontífice acudió en ayuda de Gonzalo Martínez, maestre de Alcántara, frente a las molestias causadas a éste por Alfonso $\mathrm{XI}^{95}$; pero inútilmente, ya que este monarca manejó la orden a su antojo.

En algunos casos los maestres actuaron como mediadores papales entre las monarquías para conseguir la paz entre ellas. Tenemos bastante bien documentado el caso del maestre Gonzalo Martínez de Oviedo (1337-1340). Éste, junto con el obispo de Rodez - nuncio del papa-y el arzobispo de Braga, actuaron como enviados papales para conseguir la paz entre Castilla y Portugal ${ }^{96}$.

Como señala B. Palacios ${ }^{97}$, el interés por el control de las órdenes militares se fue substanciando a lo largo de la Edad Media de formas muy diversas. En los primeros tiempos los reyes se contentaron con que los maestres les hicieran el juramento de fidelidad, y se convirtieran por lo tanto en sus vasallos, coope-

\footnotetext{
93 Bula del 8 de junio de 1338: B) A.S.V., Reg. Vat. 133, f. 56r-v.

94 Bula del 4 de octubre de 1338: B) A.S.V., Reg. Vat. 133, ff, 99v-100r, C) A.S.V., Arm. XXXI, vol. 29, ff. 95r-96r.

95 Bula del 2 de enero de 1340: B) A.S.V., Reg. Vat. 134, ff. 133r-134r.

96 Bula del 8 de junio de 1338 (al obispo de Rodez): B) A.S.V., Reg. Vat. 133, ff. 56v-57r. Bula del 8 de junio de 1338 (al maestre de Alcántara): B) A.S.V., Reg. Vat. 133, f, 57v. Bula del 10 de junio de 1338 (al obispo de Rodez): B) A.S.V., Reg. Vat. 133, f. 58v. Bula del 4 de actubre de 1338 (al maestre de Alcántara): B) A.S.V., Reg. Vat. 133, f. 100r. Bula del 4 de octubre de 1338 (al rey de Castilla): B) A.S.V., Reg. Vat. 133, ff. 99v-100r; C) A.S.V., Amr. XXXI, vol. 29, ff. 95r-96r. Bula del 4 de octubre de 1338 (al rey de Portugal): B) A.S.V., Reg. Vat. 133, f. 100r. Bula del 4 de octubre de 1338 (al obispo de Rodez): B) A.S.V., Am. XXXI, vol. 29, ff. 93v-94v.

97 B. PALACIOS MARTiN, "La orden đe Alcántara y su incorporación a la corona", en Primeras Jornadas de Historia de las Ordenes Militares, Madrid 1996, p. 58.
} 
rando así en la reconquista y en la defensa del reino. Pero ya en el siglo XIV las cosas empezaron a cambiar. Monarcas castellanos como Alfonso XI o Pedro I impusieron en ocasiones sus propios candidatos al margen de toda norma.

Con Juan I la monarquía castellana, viendo la debilidad del pontificado, acudió a una nueva estrategia de control sobre las órdenes militares: el recurso a la vía jurídica para que el papa concediese a los reyes el derecho a la designación de los maestres. Con ello se quebrantaron, por primera vez "de iure", las normas canónicas tradicionales de elección, que sólo "de facto" desde Alfonso XI se habían transgredido. Juan I aprovechó la favorable coyuntura del Cisma de Occidente, en el que tanto Urbano VI de Roma como Clemente VII de Aviñón pugnaban por atraer a su obediencia a los reyes de la cristiandad, para lograr esta generosísima concesión —que no tenía precedentes- por parte del papado.

Clemente VII de Aviñon concedió en 1383 (sic) ${ }^{98}$ a Juan I la facultad para proveer los maestrazgos de las órdenes de Santiago, Calatrava y Alcántara, si éstos quedasen vacantes ${ }^{99}$. Llama la atención la no inclusión de la orden de San Juan de Jerusalén ${ }^{100}$. Se ha apelado a causas económicas y políticas para explicarlo. Recientemente C. de Ayala apuntaba a que la orden del Hospital no fue incluida en la bula dirigida a Juan I por las grandes resistencias de dicha orden al intrusismo regio, y no por desinterés del rey Juan $\mathrm{I}^{10 !}$.

Durante el siglo XV la orden de Alcántara entró de lleno en las pugnas internas del reino castellano. Los pretendientes a las altas dignidades de la orden se alinearon con los diferentes bandos en litigio para alcanzar sus ambiciones e intereses. Por tanto, la orden vivió un proceso de división interna que amenazó los intereses regios. A principios de siglo, Fernando de Antequera - aprovechando las discordias interiores en las órdenes militares- colocó a sus hijos los infantes Enrique y Sancho en la cúspide de las órdenes de Santiago y Al-

98 Recientemente hemos localizado en el volumen 234 de los "Registra Avenionensia" del Archivo Vaticano tres bulas inéditas del 11 de julio de 1383 que demuestran la reserva papal de provisión de los maestrazgos de Santiago, Calatrava y Alcántara en favor de Juan I. En la primera parte de nuestro trabajo sólo teníamos constancia de la bula del 21 de septiembre de 1384 , ya conocida por otros historiadores. Vid. las citas correspondientes en la nota siguiente.

99 Bula del 11 de julio de 1383 (comunicación al arzobispo de Toledo): B) A.S.V., Reg. Aven. 234, ff. 665v-666r. Bula del 11 de junio de 1383 ("reservatio" en favor de Juan I): B) A.S.V., Reg. Aven. 234, f. 642r. Bula del 11 de julio de 1383 (mandato al arzobispo de Toledo): B) A.S.V., Reg. Aven. 234, f. 642v. Bula del 21 de septiembre de 1384: B) A.S.V., Reg. Aven. 238, f. 543r-v; C) A.S.V., Reg. Vat. 295, f. 136r-v.

100 Sí incluida, en cambio, en la bula de Martín V de 1421 a Juan II. Vid. infra.

${ }^{101}$ C. de Ayala Martínez, "La Orden de San Juan en la Península Ibx́rica durante el maestrazgo de Juan Fernández de Heredia", en Jornadas sobre el Maestre Juan Fernández de Heredia, Madrid, 26-2-1997 (en prensa).

Medievalia Hispanica

Hispania Sacra 50 (1998) 
cántara respectivamente. Dichos nombramientos algunos historiadores los consideran como el primer paso en el proceso de anexión de los maestrazgos a la corona ${ }^{102}$. Con ello Fernando de Antequera consiguió dotar convenientemente a sus hijos sin mermar las rentas reales y controlar sin fisuras estas órdenes militares. En la orden de Alcántara don Sancho, con tan sólo doce años, fue nombrado administrador perpetuo de la misma. Por ello se le asignó a Juan de Sotomayor, comendador de Valencia de Alcántara, para que le asistiera como regidor y gobernador de dicha orden ${ }^{103}$. Muy poco después, Fernando de Antequera consiguió la aquiescencia a dichos nombramientos por parte del papado de Aviñón: en 1410 Benedicto XIII confïrmó a los infantes Enrique y Sancho en la posesión de los maestrazgos de Santiago y Alcántara ${ }^{104}$.

Juan II y Enrique IV obtuvieron extraordinarias concesiones por parte de los papas en materia beneficial ${ }^{105}$. En 1421 el papa Martín V reconoció a Juan II la antigua costumbre que tenían los reyęs de Castilla para proveer los maestrazgos de Santiago, Calatrava, Alcántara y San Juan de Jerusalén, además de los obispados ${ }^{106}$.

Con Enrique IV se dio un salto cualitativo en el proceso que vamos describiendo: del simple derecho a nombrar el maestre se pasó al directo ejercicio de ese cargo por parte del mismo monarca ${ }^{107}$. En efecto, el 10 de enero de 1456 Calixto III se comprometió a proveer arzobispados, obispados, dignidades y maestrazgos conforme a los deseos que le expresase el rey Enrique IV108. De ese mismo día conservamos otra bula por la que el papa nombraba a Enrique IV gobernador y administrador del maestrazgo de Alcántara por un período de diez años con plenas atribuciones temporales y espirituales ${ }^{109}$. $\mathrm{Al}$ año siguiente el papa reconoció al rey Enrique por diez años los plenos derechos sobre el gobierno de las ordenes de Santiago y Alcántara ${ }^{10}$. Sin embargo, en el caso alcantarino el rey sólo se mantuvo como administrador hasta 1458 , en que colocó como maestre de Alcántara a su mayordomo Gómez de Cáceres y Solís.

\footnotetext{
$102 \mathrm{E}$. CABRERA MUÑ̃OZ, "El acceso a la dignidad de maestre y las divisiones internas de las ordenes militares durante el siglo XV", Congreso Internacional: Las Ordenes Militares en la Peninsula lbérica, Universidad de Castilla-La Mancha, Ciudad Real, ponencia del 7-5-1996 (en prensa).

103 D. LOMAX, "La reforma de la orden de Alcántara durante el maestrazgo del infante don Sancho, I411-1413", Anuario de Estudios Medievales 11 (1981), p. 759.

104 Bula del 5 de febrero de 1410: B) A.S.V., Reg. Aven. 335, ff. 203v-204r.

$105 \mathrm{~J}$. M. NiETO SORIA, Iglesia y génesis del Estado moderno en Castilla (1369.1480), Madrid 1993, pp. 350-352.

106 Bula del 8 de octubre de 1421: B) B.N., ms. 13014, ff. 96r-97r.

107 B. Palacios MarTín, Op. cit., p. 59.

108 Bula del 10 de enero de 1456: B) A.S.V., Reg. Vat. 457, f. 104r-v.

109 Bula del 10 de enero de 1456: B) A.S.V., Reg. Vat. 457, ff, 101r-102r.

110 Bula del 8 de junio de 1456: B) A.S.V., Reg. Vat. 457, ff. 296v-297v; C) A.S.V., Arm. XXXII, vol. 4, ff. $21 \mathrm{v}-24 \mathrm{r}$.
} 
Los Reyes Católicos fueron los artífices últimos de la anexión de las órdenes militares a la corona. ¿ Qué razones les impulsaron a culminar este largo proceso ? No fueron muy distintas de las que tuvieron sus predecesores para controlar el enorme poder de las órdenes.

Sobre las razones de la anexión han existido opiniones variadas. Tradicionalmente "l" se ha apelado al potencial territorial, político, económico y militar de las órdenes militares castellanas, que era un peligro para la monarquía. En el caso de los alcantarinos este potencial a finales del siglo XV era más modesto, pero no despreciable, como señala M. F. Ladero" ${ }^{12}$. Los Reyes Católicos pudieron experimentar de cerca el desafio de una facción de los alcantarinos que, al mando del depuesto maestre Alonso de Monroy, se aliaron con el monarca portugués para tratar de reconquistar el maestrazgo.

Entre los historiadores actuales algunos acentúan las razones económicas sobre las políticas. Por ejemplo, el profesor M. F. Ladero ${ }^{13}$ considera que la primera y tal vez la más importante razón para hacerse con el control directo de los señoríos de estas instituciones fue la amplia disponibilidad económica que para la monarquía suponía la posesión de dichos señoríos; y, en segundo lugar, la importancia desde el punto de vista político que entrañaba sustraer el control de las órdenes a los grandes linajes de la nobleza, la cual las había utilizado a lo largo de la Baja Edad Media como plataformas para defender sus intereses particulares, que en muchas ocasiones no coincidían con los de la corona.

Otros autores actuales ponen el acento, en cambio, en los intereses políticos. Por ejemplo, E. Cabrera ${ }^{114}$ señalaba recientemente que los motivos políticos fueron más decisivos que los económicos para vincular las órdenes militares a la monarquía.

El profesor Palacios Martín ${ }^{115}$ ha llamado la atención sobre el peligro de poner el acento en los intereses económicos. Dicha perspectiva es comprensible y necesaria, según este autor, pero puede resultar peligrosa si la consideramos unilateralmente, ya que podría llevar a una visión reduccionista del tema,

\footnotetext{
II Vid. por ejemplo: A. de TORRES Y TAPIA, Op. cit., II, p. 563.

1/2 Este autor ha escrito un buen artículo sobre el tema basado en la documentación conservada en el Archivo General de Simancas: "La orden de Alcántara en el siglo XV. Datos sobre su potencial militar, territorial, económico y demográfico", En la España Medieval 2 (1982), pp. 499-541. Este historiador ofrece en la p. 509 de este artículo un dato sorprendente para los que pensaban, por ejem. plo, en la modesta propiedad territorial de los alcantarinos: M. F. Ladero cifra en aproximadamente 7.000 kilónetros cuadrados la extensión del señorío de la orden antes de la anexión a la corona. Una superficie equivalente a lo que hoy son, por ejemplo, las provincias de Málaga u Orense.

1 i3 M. F. LADERo QUESADA, "La incorporación đel maestrazgo de Alcántara a la Corona", Hispania 42 (1982), p. 5.

114 E. Cabrera MuÑoz, Op. cit., Ciudad Real, ponencia del 7-5-1996 (en prensa).

IIS B. Palacios MartíN, Op. cit., pp. 57-58.
}

Medievalia Hispanica

Hispania Sacra 50 (1998) 
en la que se pierda la comprensión total del fenómeno que, como veremos, tuvo muchas implicaciones y significados muy ligados con el resto de la historia que España estaba viviendo en aquel momento. El doctor Palacios sitúa el hecho en un contexto más amplio: $1^{\circ}$ la incorporación de las ordenes militares a la corona, tanto por sus objetivos como por sus formas para ejecutarla, constituyó una auténtica operación de estado, planteada y ejecutada por los Reyes Católicos y sus sucesores con gran tacto, sagacidad y diligencia; $2^{\circ}$ pero se trató de una operación menor inserta en otra de mayor envergadura: la sustitución del sistema político medieval por el Estado Moderno, que posibilitaba un gobierno más centralizado y acorde con la realidad social; $3^{\circ}$ los grandes cambios en la sociedad de la época dejaron anticuadas a las órdenes militares que, para sobrevivir e insertarse en los nuevos tiempos, precisaron una profunda transformación que impulsó la monarquía.

La Baja Edad Media fue, efectivamente, la época fundacional y el escenario de los primeros desarrollos del fenómeno conocido como génesis del Estado Moderno. Por tal fenomeno se viene entendiendo un proceso de evolución, cuyos primeros momentos de desarrollo pueden rastrearse, de forma variable para las diversas monarquías occidentales, en el período comprendido entre los años 1270 y 1360 , y que experimentó una importante aceleración a lo largo de la segunda mitad del siglo $\mathrm{XV}$, pudiéndose advertir maduraciones a fines de dicha centuria. Tal proceso evolutivo tuvo como uno de sus aspectos característicos la ostensible ampliación de los recursos de gobiemo controlados por el poder monárquico, así como el incremento de sus competencias y de sus ámbitos de intervención, todo ello cada vez más fundamentado térica, jurídica y políticamente, lo que se acabará plasmando en lo que puede enunciarse como la paulatina y posterior consolidación de la posición soberana de la realeza ${ }^{116}$.

Hay acuerdo entre los especialistas sobre la existencia de modificaciones en la organización política castellana desde los inicios de la Baja Edad Media hasta fines del siglo XV y también en la dirección de los cambios. Sin embargo, las valoraciones del alcance del fenómeno y las explicaciones del proceso son muy dispares ${ }^{117}$. Obviamente no vamos a entrar aquí en dichas disquisiciones que nos alejarían mucho de nuestro tema ${ }^{118}$. Lo que queremos resaltar es que el proceso de absorción de las órdenes militares está inserto en un pro-

116 J. M. NIETO SORIA, Op. cit., pp. 17-18.

117 S. de Dios, "Sobre la génesis y los caracteres del Estado absolutista en Castilla", Studia Historica (Salamanca), III, 3 (1985), pp. 13-14.

118 Véase para estos temas la excelente síntesis y la bibliografia ofrecida por: M. A. LADERo QUESADA, "La genèse de L'Etat dans les royaumes hispaniques médiévaux (1250-1450)" en Le premier age de L'Etat en Espagne (1450-1700) (coordination: C. Hermann), Paris 1989, pp. 9-65. En la p. 49 dicho autor hace referencia a las órdenes militares. 
ceso más amplio de robustecimiento del poder regio en todos sus ámbitos de intervención. A finales del siglo XV la monarquía estimó necesaria una centralización más profunda y la creación de una serie de aparatos de Estado e instrumentos de gobiemo mediante los cuales pudiera controlar todas las esferas de la sociedad.

Las órdenes militares a finales de la Edad Media habían perdido su razón de ser, porque la reconquista había acabado tras la toma de Granada. Su poder era muy considerable y podía ser una amenaza para la monarquía, ya que estas instituciones acabaron por configurarse como un estado dentro del estado. La disyuntiva de las órdenes militares ante el poderoso Estado Moderno liderado por la monarquía era clara: o su desaparición o su integración dentro de ese Estado absolutista. Los monarcas se decantaron por la segunda solución que, a nuestro modo de ver, es más preciso denominar anexión que incorporación. Esta última denominación ha sịdo el término tradicional que han utilizado los historiadores, sin embargo, una incorporación consiste en que dos o más instituciones se unen para formar una nueva y superior, dentro de la cual permanecen y subsisten las partes integrantes. En cambio, en la anexión una institución mayor o más fuerte engloba y absorbe a otra menor que queda incluida en la primera. Creemos, por tanto, que en nuestro caso es mejor hablar de anexión: fue el poderoso Estado moderno el que absorbió a las órdenes militares, las estatalizó y las sometió progresivamente a su control absoluto.

Dicha anexión no suponía su desaparición, sino su reconversión como parte integrante, con una nueva fisonomía, del Estado Moderno. La monarquía hizo que las órdenes militares iniciaran una nueva época en su historia'19 adaptándolas a la modernidad. Los reyes, según $B$. Palacios ${ }^{120}$, supieron ponerse al frente de los valores de la Edad Moderna, al igual que la monarquía medieval había dado ejemplo de liderazgo social al ponerse al frente de los valores caballerescos de la Plena Edad Media. Fueron unos valores que hoy podemos discutir, al igual que los caballerescos, pero que en su momento, unos y otros, representaron la modernidad y consiguieron hacer avanzar la maquinaria estatal en la dirección que marcaban los tiempos, lo que les permitió colocarse a la vanguardia de la Europa que se estaba construyendo. Otros autores ${ }^{121}$ son más severos al juzgar la actuación monárquica sobre las órdenes militares: la postura de los reyes hispanos fue interesada, ya que conservaron y emplearon en su

\footnotetext{
119 Por eso consideramos las fechas de anexión de las ordenes militares como el fin de su época medieval. Pensamos que son las fechas más adecuadas para realizar el "corte histórico" que nos permite distinguir una época de otra, aunque todo "corte histórico" tenga siempre algo de artificial, pero también algo de necesario que nos permite estudiar la historia por tramos más o menos homogéneos.

120 B. PALACIOS MARTÍN, Op. cit., pp. 68-69.

121 F. FERNÁNDEZ IZQUIERDO, La orden militar de Calatrava en el siglo XVI, Madrid 1992, p. 56.
}

Medievalia Hispanica

Hispania Sacra 50 (1998) 
beneficio unas instituciones molestas y peligrosas. La anexión resultó mucho más lucrativa y ventajosa para la corona que lo que hubiera supuesto su extinción, como ocurrió con el Temple.

En conclusión, a nuestro modo de ver en la anexión influyeron múltiples factores: políticos, económicos, militares, territoriales, etc, englobados dentro del decisivo proceso de construcción del Estado Modemo, que es lo que hemos tratado de enfatizar en nuestra explicación. La solución que dieron los reyes era quizá la única que permitía la pervivencia de las órdenes militares, sin que éstas constituyeran un peligro para el nuevo Estado Absoluto.

Una vez expuesto el tema de las causas de la anexión es imprescindible pasar a la descripción del proceso de anexión de la orden de Alcántara. Para entenderlo es muy conveniente una brevísima referencia a dos precedentes: las anexiones de las órdenes de Calatrava y Santiago.

En 1485 los Reyes Católicos, tras las negociaciones abiertas en 1482, enviaron una carta a García López de Padilla, maestre de Calatrava, para solicitar que, tras quedar vacante dicha dignidad tras su muerte, en lugar de procederse a una nueva elección por parte del capítulo general, dejase el nombramiento del sucesor en manos del papa Inocencio VIII y la administración de la orden bajo Fernando el Católico, quien gobernaría la misma con la asistencia de un consejo de caballeros calatravos ${ }^{122}$. El capítulo general de febrero de 1485 aprob6 dicha solicitud, a cambio de que la orden no sufriese menoscabo en su patrimonio. Sin embargo, tras la muerte del maestre en tomo a 1489, el capítulo general de los calatravos se propuso elegir un nuevo maestre. El rey se lo impidió e hizo prevalecer el acuerdo de 1485. Un poco más tarde el rey logró una confirmación de sus derechos gracias a una bula de Alejandro VI. La anexión de la orden de Santiago fue posterior en el tiempo y más sencilla. Inocencio VIII en 1484 se reservó la provisión del maestrazgo de Santiago, en cualquier manera que quedase vacante. La orden pasó a manos de los Reyes Católicos en 1493, fecha de la muerte de Alonso de Cárdenas, último maestre santiaguista ${ }^{123}$.

Ya sólo quedaba por controlar la orden de Alcántara. Estos precedentes, especialmente las resistencias de los calatravos ${ }^{124}$, hicieron que los Reyes Católicos cambiaran de estrategia y plantearan con mayor astucia la anexión de Alcántara. Además, a diferencia de Santiago y Calatrava, la anexión se produjo en vida del maestre; lo cual llevó consigo la firma y cumplimiento de una serie

\footnotetext{
${ }^{122} \mathrm{La}$ bibliografia sobre la anexión de Calatrava es muy abundante, vid. por ejemplo: J. F. O'CALLAGHAN, "The Affiliation of the Order of Calatrava with the Order of Citeaux", Analecta Sacri Ordinis Cisterciensis 16 (1960), pp. 271-277. F. FERNÁNDEZ IZQUIERDO, Op. cit., pp. 48-56.

123 Vid. por ejemplo: A. JAVIERRE MUR, "Fernando el Católico y las 6́rdenes militares espaffolas", en Actas del $V$ Congreso de Historia de la Corona de Aragón, Zaragoza 1955, pp. 287-300.

124 B. PALACIOS MARTiN, Op. cit., p. 60.
} 
de acuerdos y compensaciones con el último maestre alcantarino a cambio de su renuncia ${ }^{125}$.

Los Reyes Católicos ya habían preparado el camino para la anexión al conseguir en $1491^{126}$ un breve de Inocencio VIII por el que el pontífice concedía a Fernando el Católico la administración del maestrazgo de la orden de Alcántara, cuando éste quedara vacante ${ }^{127}$. Pero, debido a la juventud de Juan de Zúñiga, último maestre de Alcántara, y lo incierto de un desenlace final de su vida, los Reyes Católicos -que no podían demorar en exceso la anexión de la orden- decidieron negociar directamente con él su renuncia voluntaria, sin esperar a su hipotético fallecimiento. Los reyes siguieron utilizando la inteligente táctica de implicar a la sede romana en la anexión. Dicha táctica proporcionó a los monarcas un doble beneficio ${ }^{128}$. En primer lugar, el hecho de que intervinieran en el asunto diversas instancias - la monarquía, el papado, el abad de Morimond ${ }^{129}$ - contribuyó a debilitar las resistencias, haciendo que los freires no supieran con precisión a qué institución dirigirse. El otro beneficio fue que la monarquía consiguí aumentar su poder sobre las órdenes militares y limitar la jurisdicción pontificia utilizando como instrumento al propio poder papal, que apoyó paradojicamente la táctica real de anexión casi sin cortapisas. No podemos ocultar que dentro de las órdenes militares hubo algunas resistencias. Frente a un sector "conformista" 130 había otro sector, que podríamos llamar conservador, que deseaba mantener la independencia y el gobiemo propio de las órdenes militares, sin embargo, sus intentos chocaron con la sagaz estrategia de los Reyes Católicos.

En dos bulas de junio de 1494 el papa Alejandro VI aprobó la concordia entre Juan de Zúniga y los Reyes Católicos sobre la cesión del maestrazgo de Alcántara ${ }^{131}$ y ordenó al obispo de Palencia que recibiera la renuncia de Juan de Zúniga, además de conceder la autoridad a los Reyes Católicos sobre la

\footnotetext{
125 M. F. LADERO, "La incorporación del maestrazgo de Alcántara a la corona", Op. cit., p. 6.

${ }^{126}$ Fernandez Izquierdo cita una bula del 13 de septiembre de 1488 de un libro de copias del Archivo de Simancas por la que Inocencio VIII reservaba la designación del maestre de Alcántara para que cuando quedase vacante el cargo recayera en los Reyes Católicos durante su vida (F. FERNÁNDEZ IZQUIERDO, Op. cit., p. 51, nota 8).

127 Bula del 18 de diciembre de 1491: B) Archivo de los Duques de Frías, sección Villena, catálogo $47, \mathrm{n}^{\circ} .28$.

128 B. PALACIOS, Op. cit., p. 61.

129 Recordemos que el 8 de enero de 1494 Alejandro VI confirmó al abad cisterciense de Morimond la facultad de visita y reforma que tenía sobre la orden de Alcántara: B) A.S.V., Reg. Suppl. 984, f. $107 \mathrm{r}-\mathrm{v}$.

130 B. Palacios Martín, Op. cit., pp. 56-57.

131 Bula del 18 de junio de 1494, ed. I. J. de ORTEGA Y COTES, Bullarium de Alcantara, p. 292 (inserta en bula del 18-XII-1494).
} 
orden de Alcántara como administradores legítimos de la misma ${ }^{132}$. Asimismo, en la bula del 21 de junio el papa reconocía algunos acuerdos entre Zúñiga y los Reyes Católicos: erección para Zúñiga de un monasterio al que se consignara la provincia de La Serena; renuncia de los comendadores de Zalamea y Castilnovo y aplicación de los frutos y rentas de esas encomiendas al mencionado monasterio; recepción por parte de la sede apostólica de Zúñiga y su monasterio, de tres personas nombradas por él y de diversos súbditos y bienes para que gozasen de exención jurisdiccional y estuviesen sometidos exclusivamente al papa; y otros privilegios en favor de Zúñiga. Todo ello se concedía mientras don Juan de Zúñiga viviese. Tras su muerte los bienes, privilegios y derechos debían extinguirse y pasar a la mesa maestral.

Dichos acuerdos entre los Reyes Católicos y Juan de Zúñiga fueron objeto de ulteriores profundizaciones, llegándose al acuerdo definitivo a finales de 1494. Torres y Tapia ${ }^{133}$ publicó en su crónica aparecida en el siglo XVIII el memorial entre los reyes y Zúniga, donde se especificaban detalladamente las condiciones del acuerdo final, muchas de cuyas clausulas ya constaban en la bula del 21 de junio de 1494. En 1947 C. Naranjo volvió a publicarlo ${ }^{134}$. En 1982 el profesor M. F. Ladero ${ }^{135}$ dio a conocer una copia de dicho memorial descubierta en el Archivo de Simancas, con pequeñas variaciones de poca importancia con respecto a la versión de Torres y Tapia.

Los Reyes Católicos cedieron a casi todas las exigencias de Zúñiga, hasta tal punto que no llegaron a tener un control total de la orden, por lo menos en el aspecto económico, hasta después de 1504, fecha de la muerte de Zúñiga ${ }^{136}$. Éste, durante el resto de su vida, gracias a su ventajoso acuerdo, pudo asegurarse un "retiro dorado" en el monasterio de Villanueva de la Serena y gozar de cuantiosas rentas e importantes cargos bajo la dependencia exclusiva del papado. Sin embargo, los reyes habían cumplido sus objetivos: controlaron de forma inmediata el potencial político y militar de la orden de Alcántara, las generosas concesiones se hicieron a una persona de probada fidelidad, y se aseguraron el control total del maestrazgo tras la muerte de Zúñiga. El que-

\footnotetext{
132 “(...) per apostolica scripta committimus et mandarnus quatenus ab eodem Ioanne, vel procuratore suo, ab hoc ab eo specialiter constituto resignationem huiusmodi, si illam in tuis manibus sponte et libere facere voluerit, ut prefertur, authoritate nostra hac vice dumtaxat, recipias et admittas. Eaque per te recepta et admissa, prefatis regi et regine dicta auctoritate concedas (...) (bula del 21 de junio de 1494: B) A.S.V., Reg. Vat. 869, ff. 170r-174v).

${ }^{133}$ A. de TORRES Y TAPIA, Op. cit., II, pp. 564-566. Este cronista denomina a este memorial: "Capítulos del asiento que los Reyes Católicos tomaron con el maestre don Juan de Zúñiga".

134 C. NARANJo ALONSO, "El priorato de Magacela. Memorias de una dignidad de la insigne orden de caballería de Alcántara", Revista de Estudios Extremefios, 3 (1947), pp. 405-407.

135 M. F. LADERO, "La incorporación del maestrazgo de Alcántara a la corona", Op. cit., pp. 12-14.

136 M. F. LADERO, "La incorporación del maestrazgo de Alcántara a la corona", Op. cit., p. 7.
} 
branto momentáneo de intereses económicos se vio compensado por la posesión de los ricos maestrazgos de Santiago y Calatrava.

La anexión de la orden de Alcántara en 1494 fue temporal, al igual que Santiago y Calatrava años antes, pero en 1523 el papa Adriano VI concedió la anexión perpetua de las tres órdenes militares castellanas ${ }^{137}$. Era el último refrendo canónico de una situación que, de hecho, paulatinamente ya se estaba viviendo desde 1494: la dependencia y el control absoluto de la orden de Alcántara por la monarquía y el alejamiento definitivo de aquélla de la jurisdicción eclesiástica del papa y del abad de Morimond, con todas las transformaciones que ello llevaba consigo. A nuestro modo de ver, el año 1494 fue la fecha simbólica o la piedra miliaria que marcó el fin de la época medieval y de la etapa independiente de la orden de Alcántara y el comienzo de su Edad Modema, muy distinta - por otra parte- a la anterior.

${ }^{137}$ Bula del 4 de mayo de 1523: B) A.S.V., Archivum Arcis, arm. I-XVIII, $n^{\circ}$. 2275, ff. 1r-4r.

Medievalia Hispanica

Hispania Sacra 50 (1998) 